\title{
The 63rd Edinburgh International Film Festival
}

Despite celebrating its 63rd birthday with a stupendously underwhelming Opening Night film (Sam Mendes' Away We Go), the Edinburgh International Film Festival isn't ready for retirement yet. Allegedly a comedy, Away We Go is yet another shoegazing mope through the lives of a couple of middle-class, thirty-something slackers and the existential crisis they face as they try to get to grips with adulthood and figure out the best place to settle down and spawn. Directed on autopilot by Sam Mendes, Away We Go is the type of laidback, unfunny, comedy mumbleathon normally made by earnest young indie directors and starring earnest, young indie actors with names like Zooey. Full of the kind of loveably eccentric kooks you'd cheerfully garrotte if they existed anywhere outside of smug, self-satisfied films like this, Away We Go is like being stuck at a dinner party full of Guardian columnists. And not the fun ones like Charlie Brooker. No, we're talking about the whiny, spoilt ones like Lucy Mangan. Hopefully at some point in the future, some genius will decide to programme Away We Go as one half of a double bill with Sam's recent laugh-fest Revolutionary Road.

Far funnier was Justin Molotnikov's dark, little Scottish film Crying With Laughter. Equal parts black comedy and Cape Fearstyle revenge thriller, Crying With Laughter charts the worst week in Edinburgh standup comic Joey Frisk's (Stephen McCole) life as a chance meeting with old school friend Frank (Malcolm Shields) leads to him being made homeless, framed for attempted murder, and involved in a kidnapping as old scores are settled and the guilty are punished. Scots actor Stephen McCole is fantastic as the put-upon comic and his performance is hilariously un-PC and subtly vulnerable with Shields a sympathetic, if relentless, villain and the final revelation, while signposted far in advance is, nonetheless, affecting and goes some way to explaining Frisk's angry, misanthropic stage persona.

While there were the usual honourable examples of British miserablism (A Boy Called Dad, Running In Traffic), most of this year's crop of British films were surprisingly satisfying. Mad, Sad \& Bad with its neurotic family in meltdown felt like a British-Asian version of a Woody Allen film. Except that unlike Woody's recent output, it was mildly amusing. Lindy Heymann's KICKS, however, was anything but, playing more like a Merseyside-version of Misery. Scary and compassionate, KICKS skillfully dissects Britain's obsession with celebrity culture as its two teenage wannabee WAGs (Kerrie Hayes and Nichola Burley) kidnap the object of their affections, swaggering footballer Lee (Jamie Doyle), in an attempt to stop his transfer to another team. Dark and edgy, KICKS explores the hollow ambitions of the Heat-generation without ever demonising it's teen protagonists.

Andrea Arnold's eagerly awaited Fish Tank, while a little too long and somewhat predictable, was far more satisfying than her excellent, if chilly, debut Red Road. Ostensibly a coming of age tale, Fish Tank feels more like a chav retelling of Lolita as tough, abrasive, 15 going on 35-year old Mia (Katie Jarvis) dreams of escaping her dysfunctional family and no-hope housing estate through her talents as a dancer. Slowly she becomes enamoured of her trashy mother's too-attentive new boyfriend (Michael Fassbender) and I'm not letting any cats out of bags by revealing it all ends in tears. Far from downbeat, Fish Tank is an affecting, entertaining film about life on the margins, featuring fantastic performances from first-time actress Katie Jarvis, the ever-dependable Fassbender and a scenestealing turn by Rebecca Griffiths as Mia's potty-mouthed little sister.

The best of this year's crop of British films however was the excellent Moon. A tight little sci-fi thriller more interested in the psychological effects of isolation than in explosions and wham bam action, Moon features fantastic performances from Sam Rockwell and, well, Sam Rockwell. Rockwell plays Sam, a lonely miner stationed on an isolated moonbase who's coming to the end of his 3-year contract and looking forward to getting back to his wife and daughter, his sole companion a robot called GERTY (voiced by Kevin Spacey). But after crashing his moon buggy, Sam starts to doubt his own sanity when he finds his base invaded by a stranger. A stranger named Sam. A stranger who looks exactly like him. And just how trustworthy is GERTY? Rockwell is a revelation as Sam, playing two very different sides of the same character, and Kevin Spacey makes GERTY a charming and slightly sinister presence, both caring and menacing, an echo of 2001's HAL 9000. Brilliantly directed by the artist formerly known as Zowie Bowie (David Bowie's sickeningly talented son Duncan Jones) on an ultra-low budget of $\$ 5$ million, Moon is both a fascinating study of paranoid loneliness and a thrilling vision of the near-future which stays with you long after you've left the cinema.

As ever at Edinburgh some of the most enjoyable films were part of the Night Moves strand; late night genre movies to see you through the midnight hour. Tense and claustrophobic, first-time director Stuart Hazeldine's Exam is an ambitious little shocker. Unfolding in real time, Exam's killer premise take's a disparate group of strangers, puts them in a sealed room with an armed guard, a scary invigilator (Colin Salmon) and some simple rules: leave the room and you're disqualified, talk to the guard and you're disqualified, spoil your paper and you're disqualified. However, when the invigilator instructs them to begin, the candidates turn over their papers to reveal a blank sheet without a question. As the candidates turn on each other and descend into mind-games and desperate violence the audience quickly realises that there's more at stake than just a job and that survival itself may just be the reward. l'd watch The Apprentice if it was anything like this. Salvage, with its suburban street violently quarantined by the army and secret military project gone awry borrowed heavily from George 
Romero and offered some mechanically effective scares right up until it revealed its monstrous antagonist at which point logic and tension went out the window. Also borrowing from Romero, Canadian director Bruce McDonald's Pontypool is a sly Francophile reinvention of the zombie movie. When a deadly virus turns the respectable citizens of Ontario town Pontypool into a mob of violent psychopaths it's up to talk radio host Grant Mazzy (Stephen McHattie) to try to save the day from the relative safety of his DJ booth.

This year's clutch of international films were as diverse and eclectic as one's come to expect of Edinburgh and while the last minute inclusion of Lars Von Trier's controversial Antichrist smacked of audience baiting, it fit well in a programme that served up a satisfying mix of crowd pleasers and the elegantly uncomfortable. Essentially a two-hander, the grieving couple (Willem Dafoe and Charlotte Gainsbourg) at the heart of Antichrist retreat to an isolated cabin in the woods to get over the death of their infant son. Which mostly involves Gainsbourg demanding violent sex and masturbating joylessly in the woods while she slowly dissolves into madness. Lushly shot by Anthony Dod Mantle, the first two thirds of the film are unnerving and claustrophobic, its vision of a hostile Nature a palpable third character in the film. Then a talking fox turns up, announces 'Chaos reigns,' and the increasingly unhinged Gainsbourg starts raiding the tools in the woodshed ... Overblown and hysterical, with scenes of genital mutilation and violence that wouldn't be out of place in an Eli Roth movie, Antichrist is torture porn masquerading as a serious movie which ultimately fails because you just don't care about the characters. You get the impression that Gainsbourg's character was already as nutty as a cashew tree before her son's death and Dafoe's smug cognitive therapist richly deserves the twoby-four to the balls he receives.

Based on the life of legendary French bank robber Jacques Mesrine, JeanFrancois Richet's double bill Mesrine: L'instinct de mort (Killer Instinct) and Mesrine: L'ennemi public n'1 (Public Enemy $N^{\circ} 1$ ) is a ferocious, adrenalin-fuelled ride through a criminal career that if it wasn't true no one would believe it. Featuring a charismatic, seductive performance from Vincent Cassel as Mesrine, the best way to enjoy these films is back to back. Aussie director Rowan Woods' Fragments is a Short Cuts-style ensemble piece THAT follows the survivors of a mass shooting in an American diner while Denmark's Little Soldier recycles the plot of Mona Lisa with a Gulf veteran returning to Copenhagen and slipping into a job chauffeuring a Nigerian call girl around for a jovial pimp. The pimp however is the soldier's father

\section{The Hurt Locker, directed by Kathryn Bigalow.}

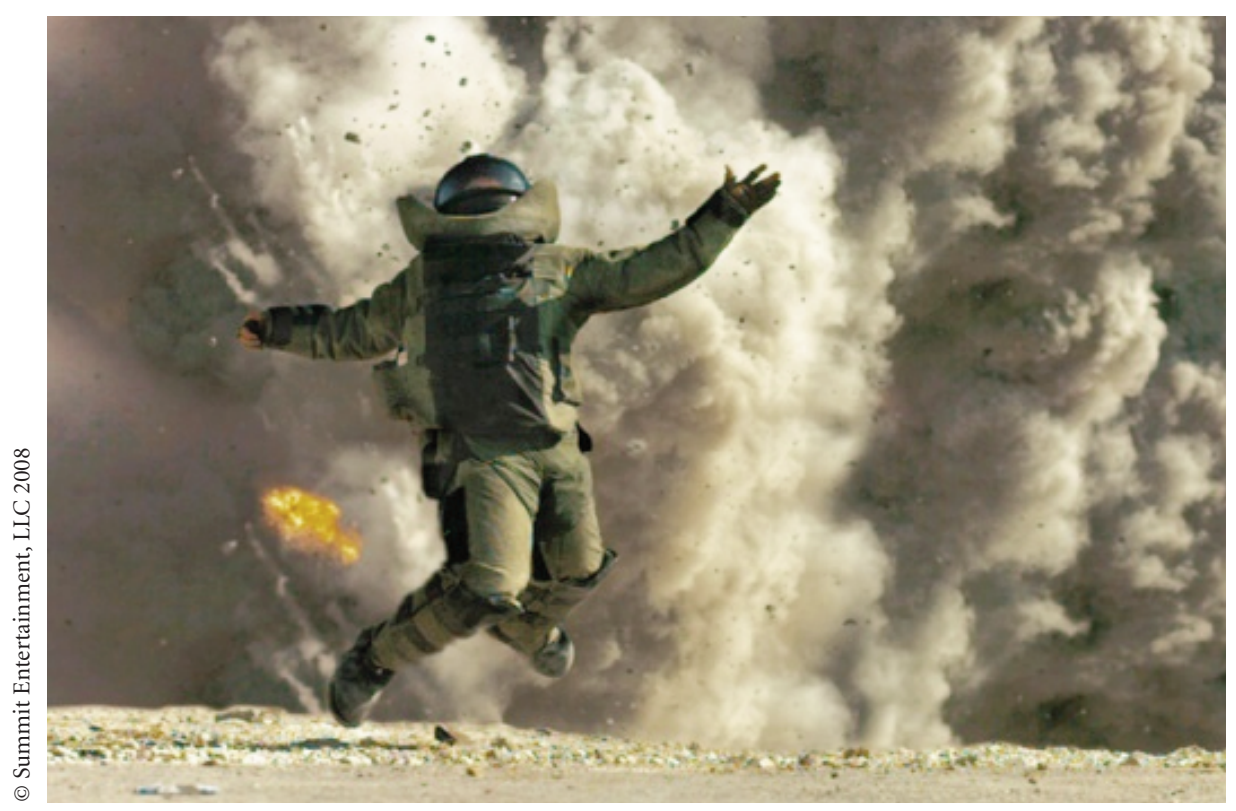

and the soldier is a brittle young woman, haunted by her experiences. Stephen Soderbergh's The Girlfriend Experience is a chilly episodic character study of a young New York escort girl (a standout performance by porn starlet Sasha Grey). Against a backdrop of the recent financial meltdown we follow Grey as she shops, dines, spends time with her clients, worries about a rival stealing her business and is interviewed by a journalist. All the while, the main topic, the only topic, of everyone's conversation is how bad the markets are doing. It's obvious that Soderbergh's heavy-handed point is that Grey's clients aren't the only ones being screwed. Disappointingly, for a film about sex, The Girlfriend Experience is damn unsexy.

If you're looking for sexy though, look no further than Kathryn Bigelow's The Hurt Locker; an adrenaline shot straight to the senses that makes war, and in particular, bomb disposal look damn sexy. From the intricate opening sequence where a US Army bomb disposal team's leader is killed, the film grabs you by the throat and doesn't let go. Focusing on the team's replacement chief, an excellent Jeremy Renner, an adrenaline-junkie who's only alive when he faces death, and his relationship with the rest of his team (the cautious, seasoned veteran Anthony Mackie and the fatalistic rookie Brian Geraghty), The Hurt Locker is more interested in putting you in the shoes of men at war, examining their motivations and mindsets, rather than action setpieces, CG effects or political grandstanding. Which isn't to say that the action scenes aren't stunning. Covering the last 30 days of the team's tour of duty in Iraq, The Hurt Locker is a bruising experience, as viscerally thrilling and visually exciting as Bigelow's previous films Point Break and Strange Days. Perhaps the first truly important film to come out of Gulf War Part 2, The Hurt Locker is a film that doesn't offer easy answers or a pat resolution but it is a tense, thrilling ride. With films like Moon and the excellent Crying With Laughter, the prognosis for next year's festival is pretty healthy.

\section{David Watson}

DOI: 10.3399/bjgp09X453945 